\title{
UMA CORPORAÇÃO RELIGIOSA. (Vida e obra da Veneravel Ordem Terceira de Nossa Senhora do Monte do Carmo da vila de São João del'Rei, durante os séculos XVIII e XIX, segundo seu próprio Arquivo) (II).
}

\author{
JOSE DA PAZ LOPES
}

da Universidade Federal de Minas Gerais.

\section{VIDA SOCIAL.}

Frei Francisco de Santa Maria Quintanilha, Provincial dos Carmelitas do Rio de Janeiro, soube ver os

"appetites de quem vive nas Minas que ou por influxo dos planetas ou pela animosidade dos mineraes tudo emprendem e tudo querem" (1).

Gente indômita e atrevida, cobiçosa, não raro cruel, cheia de força, sempre capaz do grande, toda inteligência, pronta ao sacrifício, amiga da liberdade e esforçada (2). Gente assim, evidentemente, era resultado da grande aventura para a busca do ouro e das pedras preciosas. Paulistas, emboabas de todas as partes, negros escravos, homens pardos, clérigos e funcionários do Reino, eram os elementos para a formação de nossa sociedade. Ao lado da riqueza extraida da terra, caminhava a corrupção da vida e dos costumes, animalizando a todos. 73-113.

(1). - Arq. da Ord. Terc.. L. de Termos e Del. da mesa.

(2). - LÚCIO JOSE DOS SANTOS, A Inconfidência Mineira, p. 
Mas, esta população assim constituida, foi aos poucos organizando-se, com o esforço de famílias regulares e com a autoridade do Estado que se fazia sentir. No esforço dessa organização estiveram as Irmandades separando as classes, mas unindo-as na mesma religião. A vida urbana, que se instalou nas Minas em decorrência da atividade mineradora, foi o que facilitou o aparecimento destas corporações fazendo-as viver mais intensamente.

Uma vez organizada, a sociedade mineira conheceu, com a riqueza da terra, os requintes do luxo e da cultura. Minas assistiu a festas magníficas, dançou e cantou a melhor música, vestiu a muitos com as exigências da moda, construiu cidades, igrejas e palácios e ainda formou uma inteligentzia capaz de escrever, cantar as coisas da terra, pregar idéias e revoltar-se.

E neste quadro geral que vemos a sociedade religiosa dos Irmãos do Carmo, da Veneravel Ordem Terceira da Vila de São João del-Rei. Lembramos aqui Oliveira Vianna, quando nos diz:

"Essa famosa corrupção de costumes, que lavra a sociedade da época das minas, tem o campo das suas devastaçốes quase que inteiramente limitado às classes inferiores. Toda a classe superior se esforça e luta, ao contrário, por manter intactas a pureza do sangue e a pureza do caráter" (3).

A Ordem Terceira do Carmo, constituida de um pequeno grupo, de gente bem nascida, de homens brancos selecionados pela riqueza, cor e costumes, representou o esforço e a luta da manutenção de uma elite viva e honesta. Na sua sede de escolher, esta pequena sociedade se manteve à distância de outras camadas sociais, tornando-se impermeavel a elas, fechando-se em si mesma numa atitude narcisista.

O melhor veiculo para conhecermos a organização e o procedimento de vida do sodalício do Carmo de São João del-Rei é o seu Compromisso. Esta é a denominação usada por quase todas as Irmandades para designar seu Regimento Interno ou Estatuto. O Compromisso do Carmo de São João del-Rei tem o nome de Actas Leis e Estatutos da Veneravel Ordem $3^{a}$ da Penitencia da Sempre Virgem Maria do Monte do Carmo. E o mesmo Estatuto usado pela Ordem Terceira da cidade do Rio de Janeiro e que foi exposto pelo Frei Manoel Ferreira da Natividade, Reformador e Visitador Geral dos Carmelitas em todo o Estado do Brasil, no ano de 1697. Fundada nas

(3). - OLIVEIRA VIANNA, ob. cit., p. 139. 
Minas o sodalício de São João del-Rei, tudo indica que desde o início esteve em vigor este Estatuto, sofrendo alterações quando necessárias - as provas estão nos Termos e Deliberações do mesmo sodalício se bem que a cópia guardada no arquivo, única que possuimos, data de 1840. Compreende o Estatuto 35 longos Capítulos, onde se sente o tom incisivo, autoritário, muito próprio de Regras de Ordens Religiosas, sendo usuais as expressões" queremos", "mandamos", "decretamos", "ordenamos" e ainda apelando para o "preceito formal de obediência".

Dissemos que a Veneravel Ordem do Carmo era constituida de um pequeno grupo. O Estatuto não define o número de Irmãos associados. Em nossa pesquisa encontramos apenas uma estatística, assim mesmo um pouco tardia. Em 1855, o Provincial Carmelita do Rio de Janeiro, desejando fazer um levantamento geral dos sodalícios do Carmo, indagava por carta o número de associados de São João del-Rei. A resposta da Mesa Administrativa informava possuir a Ordem 1.568 Irmãos vivos, sendo 620 Irmãos e 948 Irmãs. Admitia, pois, em seus quadros, homens e mulheres. Mesmo baseado nos dados acima, em que há maior número de Irmãs, informamos que toda a direção administrativa da Ordem era constituida de homens.

O controle, as decisões importantes e mesmo as secundárias estavam a cargo de uma elite, a Mesa Administrativa, composta dos seguintes membros: O Prior, o Sub-Prior. o Secretário, o Tesoureiro, o Procurador, às vezes denominado de Zelador, os Definidores, em número de seis, o Vigário do Culto Divino, o Sacristão, o Enfermeiro e finalmente, o Comissário que era um sacerdote. Cada membro possuia função definida e com mandato de um ano. A Mesa, uma vez reunida, era denominada Consistório, Definitório ou ainda seus membros recebiam o curioso, mas significativo nome de Discretos.

O Prior era a maior autoridade da Ordem, possuindo

"toda a jurisdição sobre o temporal sem mais dependência" e definindo tudo para o bem da Ordem Terceira no "seu governo político e temporal" (4).

A presença do Prior se fazia sempre necessária, presidindo e orientando os trabalhos da Mesa e nas decisões, em caso de empate, o seu voto era de qualidade. Tanta importância dava-se ao Prior, que uma vez servindo três vezes no cargo, sem precisar de ser em

(4). - Actas Leis e Estatutos da Veneravel Ordem Terceira do Monte do Carmo, Cap. 10, art. 3. 
seguida, era considerado "jubilado" e gozava de alguns privilégios. Podia, se assim o desejasse, assistir a todas as reuniões da Mesa com direito a voto; participava, prioritariamente, das Juntas extraordináiras convocadas em ocasiōes especiais; e, uma vez faltoso, tinha foro especial, pois, só poderia ser admoestado nos limites fechados da Mesa.

O Sub-Prior, assistia o Prior e, quando necessário, por impedimento deste, substituia-o com todas as regalias e responsabilidades. Os Irmãos Secretário e Tesoureiro tinham as ocupações de praxe para estes cargos em toda e qualquer associação. O Secretário cuidava dos livros, redigia atas, memórias, termos e correspondência, enquanto o Tesoureiro cuidava dos cofres, da vida financeira da Ordem, conservando em dia as contas, despesas e a escrita. O Procurador era o Irmão que representava a Ordem fora de seus limites internos sempre que assim as exigências o obrigassem. Em qualquer demanda, devia o Irmão Procurador estar presente defendendo os interesses da Ordem. Assim, em 1773, dirigia-se ao Rio de Janeiro, para solucionar "importantes cauzas e dependências" (5), o Irmão Procurador João Cosme Rebelo. Nestas oportunidades, por dever de ofício, tinha o Procurador acesso a todas as coisas da Ordem, para poder agir.

Os Definidores formavam peça importante na organização de comando da Ordem. Constituiam "o corpo da Meza e da Ordem", uma espécie de Conselho Deliberativo nas empresas modernas, verdadeiro corpo de assessoramento para as deliberações vitais. Eram em número de seis e tão importantes que, conservando a hierarquia, um Definidor substituia o Prior ou Sub-Prior no legítimo impedimento destes. O lugar de reuniões da Mesa, que se fazia na parte lateral da Igreja do Carmo, tomava o nome de Definitório, pois, ali juntos, definiam os traços de ação da Corporação do Carmo.

O Irmão Vigário do Culto Divino tinha por dever zelar pelas coisas do serviço de Deus:

\footnotetext{
"bem inclinado, curioso, e zelozo, amigo do Serviço de Deos, e que seja perfeito em todas aquellas couzas, que forem do Culto Divino" (6).
}

Estava a seu cargo a fábrica do culto, o fundo específico para os atos sagrados, devendo empenhar-se para que os ornatos e o esplendor

(5). 一 L. de Termos e del. da mesa.

(6). - Estatutos 8, 1. 
dos atos litúrgicos estivessem sempre a altura da dignidade da Ordem Terceira. O Irmão Sacristão - o Estatuto fala em dois Sacristães era ligado ao Irmão Vigário do Culto Divino, diretamente subordinado a ele encarregando-se da preparação dos atos divinos e zelando pela ordem e limpeza de toda a igreja.

Os cargos de Comissário e de Enfermeiro serão objeto de considerações em outra parte de nosso estudo. Fazemos lembrar ainda a pessoa do Irmão Mestre de Noviços, o homem que conhecia todo o Compromisso e era encarregado da iniciação dos noviços na vida da Ordem. Figura um tanto paternal pelo dever de ofício, mesmo sendo eleito como qual quer outro membro, não tomava parte nas deliberações imediatas da Mesa.

"O lugar do Mestre dos Noviços, na Igreja donde se assentão os Irmãos, será sempre junto com o dos seus Noviços, para que possa ver se elles estão com toda aquella modestia, que o lugar Sagrado pede" (7).

Mas, se não estavam entre os da Mesa, era estimado, respeitado e, quando necessário, ouvido.

Chamamos a atenção para o fato, reputado de vital importância pela cúpula administrativa, da precedência e dos lugares na Mesa do Definitório. Ao tratar de cada Irmão da Mesa, o Estatuto tem o trabalho imediato de distribuir o assento de cada um, com a finalidade de evitar atritos, que, como veremos, mesmo assim, foram inevitáveis. Desta forma, como ilustração, podemos lembrar o título do Capítulo Segundo do Estatuto da Ordem: Dos Requisitos, lugar, qualidade, $e$ obrigação do Ir. Prior.

Assim toda a ação diretiva, repetimos, era de homens. Mas, tambem existiam as mulheres tituladas. Havia, pois, a Priora, a Sub-Priora, as Definidoras, a Zeladora, a Enfermeira, a Vigária do Culto Divino e a Sacristã. Eram distinções que projetavam as pessoas que recebiam estes títulos, sem entretanto, possuirem qualquer poder de decisão na administração, direção e comando da Veneravel Ordem.

Notamos ainda na organização da Ordem Terceira pessoas do Andador e do Cobrador. O Andador - o Estatuto fala de dois Andadores - já o disemos, era o síndico geral e que se fez muito necessário nos longos anos de construção da Igreja do Carmo. O Cobrador e seu auxiliar tambem não eram menos úteis, uma vez que procuravam recolher os fundos para a vida da asociação.

(7). - Estatutos 11, 3 . 
Depois de considerarmos a direção da Ordem, passemos a examinar o importante assunto do recrutamento dos associados. Podemos adiantar que era muito severo, com o rigor da procura da perfeição. $\mathrm{O}$ indivíduo só era admitido

"com tanto que concorrão nelles as condições" e outros requisitos "dos quaes não poderá a Meza por nenhum cazo dispensar" (8).

Em tudo se deveriam observar as severas linhas das normas estatutárias, responsabilizando a Mesa e pessoas pelos erros voluntários e involuntários.

Sem qualquer subterfúgio, a primeira seleção era de ordem racial. O Estatuto é muito claro:

"A $1^{\text {a }}$ condicção, ou requizito, que ha de ter o Irmão, ou Irmã, que houver de entrar na Ordem $3^{\text {a }}$, hé, que deve ser limpo de sangue, sem alguma raça de judêo, mouro, ou mulato, ou de outra qualquer naş̧ão" (9).

Era uma exigência comum a muitas Irmandades. Diogo de Vasconcellos, cita a Irmandade do Sacramento da Vila do Carmo, em cujos estatutos primitivos se lia:

\section{"não podem entrar nesta Irmandade judeus, mulatos e here- ges" (10).}

Fritz Teixeira de Salles trata do mesmo assunto em todo o capítulo Primeiro de sua obra (11) .

Fazia, pois, a Ordem do Carmo de São João del-Rei parte do grupo de associações de brancos puros, imaculados, sem a pinta do sangue negro e sem os azares do parentesco com algum judeu, mouro ou outra nação infecta. Deveria o candidato ser tambem de bom tronco cristão. É o que se lê no Estatuto ao tratar dos Irmãos Andadores, que entre outras qualidades, deveriam trazer a de

"homens Christões Velhos, limpos de geração" (12).

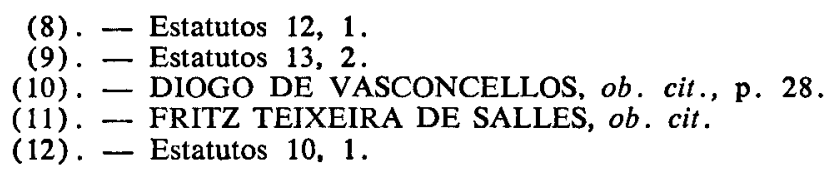


A sindicância era pois, severa. As propostas deveriam satisfazer largos interrogatórios, para que os Informadores tudo apurassem, apontando o nome dos pais e avós dos candidatos, revelando as raizes familiares limpas de sangue e de qualquer suspeita na fé.

No fim do século XIX, quando estas informações eram mais descuidadas, a Ordem Terceira do Carmo viveu momentos desagradáveis com a admissão em seus quadros de um negro, de nome Boanerges, que fez esvaziar a Igreja quando compareceu às cerimônias da Ordem, vestido com o hábito de Irmão do Carmo. Irmão do Carmo, era sinônimo de branco, como nos informa Zoroastro Passos (13).

O negro não era só abolido da lista dos associados. Em sua capela, proibia-se a entrada de negra ou mulata que, por acaso, acompanhasse sua ama, Irmã do Carmo, para um ato religioso, exceto para estender os tapetes às suas senhoras e depois esperar, lá fora, o término das cerimônias. Esta norma era tão severa, que caia sob o preceito formal da obediência e dela ninguem estava isento, nem mesmo os Irmăos mais qualificados, sem receber punição (14).

Talvez se fizesse ressalva aos mulatos músicos, que certamente abrilhantavam missas e procissões nas pompas do Carmo. A exceção encontraria apôio na boa qualidade artística daquela gente, e eram considerados apenas serviçais por contrato e remuneração.

Era, pois, a Ordem Terceira do Carmo uma sociedade segregacionista, atenta aos inconvenientes da mistura, satisfazendo as exigências de sua vaidade.

"Sociedade aquela, diz Diogo de Vasconcellos, em que só a morte igualava os homens" (15).

Existiam outras corporações religiosas de homens brancos em São João del-Rei, que juntamente com a do Carmo, forçavam aos negros e mulatos, a se unirem em outras associações próprias para o seu meio, onde na devoção de outros santos encontravam tambem a satisfação. Assim os homens pretos veneravam Nossa Senhora do Rosário e os pardos a Nossa Senhora das Mercês, construindo tambem suas capelas, modestas e acanhadas: uma, a do Rosário, que fica próxima

(13). - ZOROASTRO VIANNA PASSOS, Em tomo da História do Sabará, p. 7.

(14). - Estatutos 35. 12.

(15). - DIOGO DE VASCONCELLOS, ob. cit., p. 29. 
à Matriz, no lado oposto à Igreja do Carmo, e a outra, das Mercês, atras da Matriz.

Alem da limpidez da descendência, exigia-se do sócio a pureza dos costumes, o bom procedimento de sua vida, o seu conceito público de homem probo. O Estatuto pedia do candidato em sua petição, a declaração do estado civil, onde era morador, onde nasceu,

"para que com todas estas circunstâncias se possa tirar a sua informação com toda a diligência, e clareza" (16).

Havia grande cuidado nestas diligências e investigações para que alguem pudesse tomar o santo hábito. Pesava sobre as consciências dos informadores qualquer falta de exatidão, pois, poderia prejudicar irremediavelmente a petição ou introduzir, em meio tão puro, alguem que não estivesse em condições. Era passivel de anulação a aceitação que não estivesse de acordo com as normas.

E de se lamentar, no atual arquivo, a ausência desses interrogatórios e investigações prévias na admissão de um Irmão do Carmo. Provavelmente foram estes papeis destruidos, pois, muito se recomendava segredo e discrição por parte dos Irmãos da Mesa - eram estes denominados Discretos - para a ninguem ofender. Mas, havia no Estatuto a ordem de anotar e arquivar todas as recusas em "livro dos reprovados", para que estes, em tempo algum, fossem admitidos.

Eram inúmeras as condições exigidas para a entrada e que se referiam aos costumes. O candidato deveria ser livre de toda infâmia de delito, não ser escandaloso, sem qualquer fama ruim ou má suspeita e muito menos ter sido condenado em juizo pelos seus crimes. Para acudir às obrigações da Ordem o pretendente deveria ser de bom procedimento e de bons costumes. Qualquer fama de ladrão, bêbado, boêmio, jogador público era impedimento mais do que legítimo para ser Irmão do Carmo, que procurava na vida a virtude e a austeridade para servir a Deus e a Nossa Senhora (17). Não podia ser aceito quem tivesse oficio vil:

"não poderá ser admittido homem algum que tenha officio vil, pelo qual se siga de discreto a Ordem" (18).

(16). - Estatutos 13, 4-9.

(17). - Estatutos 13, 3-4.

(18). - Estatutos 12,6. 
Este artigo do Estatuto mostra bem claro a exigência do requinte de vida para pertencer à Ordem Terceira. Não se concebia compativel com o hábito do Carmo, o indivíduo que se entregasse a serviços mecânicos ou que, nos açougues, retalhasse os animais sujando as mãos e a roupa.

Outra proibição registrada era a dos egressos da Ordem Terceira de São Francisco ou de outra qualquer Irmandade, por expulsão ou mesmo de livre vontade.

Para conceder o alto privilégio de o assaciado andar sempre vestido com o hábito, a Mesa, de acordo com o Estatuto, deveria redobrar os cuidados em apurar a reputação, o modo de vida e os costumes do candidato. Estabelecia-se a idade mínima de quarenta anos, em exigência de maior amadurecimento e responsabilidade e ainda

\footnotetext{
"possibilidade bastante para viver sem andar mendigando pelos lugares públicos com descredito do Habito" (19).
}

Em idade inferior à estabelecida, se fazia necessário a licença do Ordinário e, se do sexo feminino, a autorização do marido para mulher casada e dos pais para a solteira. Entretanto, ao que tudo indica, não se praticou este costume de trazer sempre o hábito entre os Irmãos Terceiros de São João del-Rei. A incomoda veste era substituida pelo bentinho, que trazia a imagem e o emblema de Nossa Senhora do Carmo bordado em pano e com cordões, que era dependurado no pescoço sob outras roupas.

Outra restrição era de idade para as mulheres.

"Nenhuma mulher q. passe de 50 annos poderá ser 3 a, salvo o forem mulheres de Irmão, ou Benfeitoras da Ordem, e sem esta condição se não poderá admittir" (20).

$\mathrm{Na}$ prática, principalmente, quando a mulher estava à morte, era ela admitida acima da idade estabelecida, uma vez que se exigia uma boa esmola e presumia-se assim que a pessoa se tornasse benfeitora da Ordem.

Para que uma Irmã Terceira atingisse o Priorado, várias eram as exigências: ter idade mínima de quarenta anos, ser a mais exemplar das companheiras, nunca ter sido difamada e ser professa cinco anos.

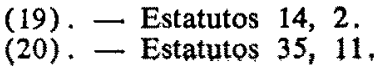


Depois de toda a investigação era o processo apresentado à decisão da Mesa, que fazia minucioso julgamento. Os casos pendentes eram resolvidos através da votação sendo soberano o resultado apresentado. Uma vez admitido o candidato, em dia próprio se fazia a solene cerimônia da profissão na Igreja da Ordem, na presença da Mesa e dos demais Irmãos e recebia do Comissário o sagrado hábito. Somente por legítimo impedimento, em casos excepcionais, como de doença grave, era possivel a profissão ser feita em casa. Mas, se houvesse cura do doente, este deveria repetir a profissão na Igreja .

Entretanto, a grande seleção no apurado recrutamento dos Irmãos do Carmo era a econômica. Se Irmão do Carmo significava branco, significava tambem rico, bem posto na vida, de alta linhagem, homem de êxito e realizado. Fritz Teixeira de Salles, fazendo uma apreciação geral sobre a categoria sócio-econômica dos associados das Irmandades religiosas no interior de Minas, afirma que à Ordem Terceira de Nossa Senhora do Carmo pertenciam comerciantes ricos e altos dignitários (21) . Zoroastro Passos, referindo-se à Ordem do Carmo, diz que ela foi a agremiação dos nobres de Sabará (22). A Corporação do Carmo de São João del-Rei não constituiu exceção no quadro geral das Minas. Ela foi tambem a Igreja dos Comendadores. Desembargadores, Juizes, Capitães-Mores, Viscondes, Barões, Doutores, Políticos, Funcionários, Fazendeiros, Comerciantes, Mineradores. Banqueiros, Sacerdotes, Capitães e Alferes. A ilustração com nomes é abundante e pode ser multiplicada várias vezes. Assim. citamos o comerciante José Maximianno Batista Machado, o Comendador Carlos Baptista Machado, o Capitão-Mor Mathias Gonçalves Movnhos. o comerciante e o precursor das atividades bancárias em São João del-Rei Francisco José Teixeira (Barão de Itambé), o Capitão Leandro Barbosa, o Barão de Entre-Rios, o Visconde de Rio Novo. o alferes Joaquim F. de Oliveira, o advogado, político e jornalista Severino de Resende, o Padre José Maria Xavier e outros muitos.

A Ordem em seu Estatuto não esconde a sua predileção e escolha em relação aos homens abastados. Somente os ricos são verdadeiramente os chamados. A eleição do Prior deveria, de acordo com as normas, recair sobre homem nobre por geração ou, dando maior extensão à palavra nobre, "pelo tracto com que viver", para que pudesse impor respeito e maior autoridade. Devia ainda o Prior ser de bons costumes, benévolo no tratamento dos Irmãos, zeloso para assistir e aumentar os bens da Ordem e caridoso para se inclinar ao bem das almas dos Irmãos defuntos e ao remédio dos pobres. Mas,

(21). - FRITZ TEIXEIRA DE SALLES, ob. cit., p. 47.

(22). - ZOROASTRO VIANNA PASSOS, ob. cit., p. 7. 
“porque esta em uzo que os Irmãos Priores fação no seu tempo algum gasto em benefício da Ordem, hé tambem necessario que tenha cabedal para assestir ao dito gasto" (23).

Para o cargo de Tesoureiro devia tratar-se de pessoa muito zelosa

"que pague pontualmente as esmolas da sua obrigação",

que tenha talento para o tal cargo e bastante notícia sobre contas e

“juntamente possuir algum bem" (24).

Citamos os casos do Irmão Prior e do Irmão Tesoureiro como amostragem. Não eram somente eles que deveriam ter dinheiro. Eram todos. Todos pagavam a entrada na Ordem como associados, as anuidades, as esmolas comuns e inúmeras subscrições para atender negócios vários. O neo-professo alem de providenciar o hábito do Carmo, que não podia ser emprestado, a correia, as contas do rosário, e uma vela de uma libra, fazia o pagamento da taxa de entrada. Esta taxa variava de acordo com a idade do Irmão, como nos prêmios das modernas Companhias de Seguro. Como amostra apresentamos a seguinte tabela de preços, que, embora um pouco tardia - é de $1^{\text {9 }}$ de outubro de 1890 - foi a única que encontramos completa:

\begin{tabular}{lr}
\multicolumn{2}{c}{ Entrada de Irmãos: } \\
Até 30 anos & $15 \$ 000$ \\
$30-40$ & $40 \$ 000$ \\
$40-50$ & $50 \$ 000$ \\
$50-60$ & $60 \$ 000$ \\
$60-70$ & $70 \$ 000$ \\
70 em diante & $100 \$ 000$ \\
Artigo de Morte & $100 \$ 000$
\end{tabular}

O novo professo deveria ainda prometer - a promessa era lavrada em termo - que, mensalmente, as esmolas de praxe seriam saldadas (25).

A tabela progressiva acima apresentada tinha uma razão. Entre os muitos requisitos exigidos na admissão, um rezava que não fosse o indivíduo de muita idade, para que a Ordem não gastasse no seu en-

(23). - Estatutos 2, 1.

(24). - Estatutos 7, 1.

(25). - Estatutos 12, 7. Estatutos 13, 18-19. 
terro maior quantia do que aquela doada por ele nas esmolas continuadas e costumadas.

Alem das entradas e anuidades, cobravam-se jóias para aqueles que servissem à Mesa. O mandato de um ano para a Mesa Administrativa era um expediente para que novas jóias fossem pagas, aumentando os bens da Ordem. Em carta da Mesa ao Provincial da Ordem do Carmo, no Rio de Janeiro, Frei Diogo dos Anjos Rocha, em 1825, é feito o pedido de aumento de jóia do Prior e da Priora de $100 \$ 000$ para $200 \$ 000$,

\footnotetext{
"por que para estes cargos se escolhem pessoas mais abastadas que sem vexame e detrimento possão satisfazer".
}

Era, em tempos difíceis das Minas, uma importância consideravel em comparação com jóias de outros Mesários em outras Ordens Terceiras. Assim, segundo informações de Fritz Teixeira de Salles, em 1837, na Veneravel Ordem Terceira de Nossa Senhora das Mercês dos Perdóes, o Prior pagava a mesada de $60 \$ 000$, e a Priora $50 \$ 000$. Mais séria era a situação da Ordem do Carmo de Sabará em 1817,

"que em razão da decadência dos tempos erão demaziadas as mezadas"

e fixava-se uma redução no pagamento (26) .

A tabela completa das jóias do Carmo de São João del-Rei que transcrevemos, tambem é de 1890:

JOIAS.

$\begin{array}{lr}\text { Prior } & 200 \$ 000 \\ \text { Sub-Prior } & 100 \$ 000 \\ \text { Secretário } & 20 \$ 000 \\ \text { Tesoureiro } & 20 \$ 000 \\ \text { Procurador } & 20 \$ 000 \\ \text { Vigário do Culto Divino } & 100 \$ 000 \\ \text { Definidor } & 20 \$ 000 \\ \text { Sacristão } & 15 \$ 000 \\ & \\ \text { Priora } & 200 \$ 000 \\ \text { Sub-Priora } & 100 \$ 000\end{array}$

(26). - FRITZ TEIXEIRA DE SALLES, ob. cit., pp. 49, 60-61. 


$\begin{array}{lr}\text { Definidora } & 20 \$ 000 \\ \text { Zeladora } & 15 \$ 000 \\ \text { Enfermeira } & 15 \$ 000 \\ \text { Vigária do Culto Divino } & 100 \$ 000 \\ \text { Sacristã } & 15 \$ 000\end{array}$

Como se vê, tambem as Irmãs contribuiam com mesadas em proporções idênticas às dos homens, mesmo não tendo ação executiva, como vimos. Era, sem dúvida, outro expediente para apurar mais dinheiro.

Havia a proibição nas Actas Leis e Estatutos da recusa aos cargos da Mesa com ameaças das penalidades. Mas, não havia necessidade, pois, eram disputados e desejados por todos que queriam projetar-se na vida da Ordem. Havia mesmo uma corrida aos cargos. Foi, por exemplo, o que fez o Irmão F. Antônio Fernandes, em 1834, que, eleito $3^{\circ}$ Definidor e não podendo tomar posse imediata, se apressou em efetuar o pagamento da jóia para salvar o direito ao lugar. Funcionava aí um bom serviço de relações públicas. Todas as vezes que era eleito um Irmão para determinado cargo, recebia logo, gentilmente, uma carta de comunicação.

A Corporação do Carmo possuia tambem seus meios de autodefesa. Não bastava nela entrar, era preciso ficar. A permanência do Irmão dependia muito dele, de seu comportamento e atitudes. As transgressões estavam sujeitas às várias penas, que iam desde a simples admoestação, até aos atos de penitência e mesmo expulsão dos quadios da Ordem. Havia no Estatuto o capítulo específico das penas, tão comum aos Códigos. O Capítulo XXIX intitulava-se: Das Couzas por que os Irmãos poderão ser expulsos, e riscados dos Livros da Ordem.

Era expulso por sentença da Ordem, sem qualquer admoestação, o Irmão que, depois de noviço ou professo, cometesse crime de infâmia e fosse castigado pelo juizo secular ou eclesiástico. Depois de três admoestações, eram expulsos os membros da Mesa, que, indiscretos, não guardavam segredos nas matérias devidas ou não eram limpos de mãos.

Todo Irmão que, com escândalo público, desobedecesse ao Padre Comissário, ao Prior ou a outro qualquer Mesário, era imediatamente excluido. Estavam ainda sujeito às severas penas da expulsão os mal informadores, quando da aceitação de um novo sócio; os contumases portadores de algum vício desacreditando o hábito da Ordem, como o 
"aluado de sues sentidos por cauza de alguma bebida, ou mancebia, e outros assim semelhantes",
\end{abstract}

os faltosos sem impedimento legítimo, a critério da Mesa, à procissão que a Ordem fazia do enterro na Sexta-Feira Maior com toda a solenidade; toda mulher Irmã

"que com escândalo não fizer vida com seu marido", "por que mal poderá servir a Deos" na Ordem, "quem serve no mundo, diabo e carne, inimigos capitaes da alma";

era tambem expulso da Ordem quem faltasse o respeito à Igreja, nela praticando jogos proibidos ou ainda nela fazendo merendas; finalmente, era punido com a severidade da exclusão, quem, quando do acompanhamento de algum Irmão à sepultura, abandonasse o mesmo para acudir o de outra Irmandade que se processasse ao mesmo tempo (27).

Atraves das atas e deliberações da Mesa, podemos mostrar alguns casos em que estão envolvidos nomes de Irmãos em atritos com a Ordem do Carmo. Em termo de 1769, são chamados de rebeldes os Irmãos Antônio João Coelho e José Teixeira Bragança. Desconhecemos, por discrição do mesmo termo, qual foi o delito que cometeram. Mas, ambos foram tocados pelo arrependimento e estiveram sujeitos

$$
\begin{aligned}
& \text { "a penitencia de orarem com braços em cruz, abraçando } \\
& \text { os demais Irmãos" }
\end{aligned}
$$

na presença de todos. Saudavel penitência que foi aceita por eles e religiosamente cumprida. Entretanto, receberam a punição do rigor da lei,

"não podendo mais para o futuro pertencer a Meza".

No mesmo ano de 1769 , registra-se a exclusão do Irmão José Araújo Dantas que se recusou, "com contumacia", a aceitar sua eleição para um cargo de mesário.

Fato curioso e que mostra com clareza a mentalidade da gente do Carmo, ocorreu no ano de 1764. Tendo falecido os Irmãos Luiz da Costa Ferreira e Miguel Gomes,

(27). - Estatutos 29. 
"um não foi acompanhado à sepultura, a outro quase sucedia o mesmo".

O acontecimento causou mal-estar entre todos, "provocando murmurações" no meio dos Irmãos e foi necessário a Mesa vir a público dar uma explicação. Infundada era qualquer reclamação por ignorância do que estava estabelecido no Estatuto, Capítulo XXVII, artigo 4!:

"Nenhum Irmão poderá ser Sepultado, e acompanhado com os Irmãos $3^{\circ} \mathrm{s}$, sem ordem do Ir. Secretario, ou Procurador, os quaes primeiro farão exame se tem satisfeito com as obrigações, e esmolas a que era obrigado, e sem satisfazer a tudo, tendo possibilidade, o năo mandarão enterrar, nem o accompanharão, por não ser justo, que a Ordem não tendo rendas faça despezas".

Após os esclarecimentos da Meza, foi encaminhada petição ao Reverendíssimo Padre Provincial Carmelita de endurecimento daquela norma, recebendo acolhida desta autoridade:

"os Irmãos que sendo admoestados não pagam, passados sinco annos devem ser expulsos".

A nova deliberação foi publicada em edital e, uma vez afixada na porta da Igreja, entrou em vigor.

A Ordem Terceira do Carmo de São João del-Rei, rica, não se mostrou como modelo de asistência social a seus filiados e a outros por extensão. Referindo-se às Irmandades, Augusto de Saint-Hilaire observa:

"constroem-se templos sem necessidade, fazem-se despesas loucas para celebrar os padroeiros com festividades quase pagãs, e, como já o fiz notar alhures, não se pensa em fundar estabelecimentos de caridade, hospitais, escolas gratuitas, etc., etc." (28).

Isto se dá tambem na Ordem do Carmo. Nos primeiros termos que possuimos, lê-se com dificuldade a palavra hospital. Pensou-se em construir um, seguindo-se iniciativa da Ordem Terceira do Rio de Janeiro. Foi idéia que jamais se colocou em prática. Em ofício-cir-

(28). - AUGUSTO DE SAINT-HILAIRE, Viagem pelas Provincias de Rio de Janeiro e Minas Gerais, p. 159. 
cular do Governo Provincial de Minas Gerais, de 18 de setembro de 1873, assinado por Francisco de Paula Cordeiro de Negreiros Lobato, pergunta-se à Ordem do Carmo de São João del-Rei se ela mantinha hospitais, casas de recolhimento, quais os socorros distribuidos pela Associação em quanto eles importavam. A resposta da Mesa do Carmo foi negativa a todos os itens.

Não se fala em qualquer projeto de asilo. Em termo de 19 de outubro de 1890, por iniciativa do Irmão Secretário, Dr. José Moreira Bastos, foi proposta a criação de uma escola de sexo masculino, unicamente para os filhos dos Irmãos Terceiros e debaixo da imediata fiscalização da Mesa Administrativa. A proposta foi aprovada e nomeada uma comissão para angariar donativos para a escola. $\mathrm{Na}$ oportunidade, o Dr. José Moreira Bastos ofereceu para o patrimônio dela a importância de 500\$000; outro Irmão, Daniel Antônio de Paiva, ofereceu $100 \$ 000$, com a condição de que a escola fosse mista; caso contrário, reduzia sua oferta a $50 \$ 000$. Entretanto, tudo ficou em palavra; a escola jamais funcionou.

Contudo, não se esqueceu a Ordem de seus doentes. Como outras corporações similares, possuia o Irmão Enfermeiro, encarregado de visitar os Irmãos enfermos. Adoecendo qualquer Irmão, deveria mandar comunicar ao Andador para que esse enviasse o Enfermeiro e os demais Irmãos para o cumprimento da caridade da visita.

"Se o Ir. Enfermeiro vir que os Irmãos enfermos padecem alguma necessidade, por se acharem pobres, será obrigado a representá-lo a Meza, para que esta o soccôrra com o necessario" (29).

Cuidou a Ordem tambem dos Irmãos pobres, mas com os cuidados que assunto tão delicado exigia. Uma vez feita a petição de ajuda por parte do Irmão, a Mesa determinava

"logo diligencia por se informarem da necessidade do que pede a dita esmolla".

Verificada a situação de pobreza, a Ordem lhe dava cobertura de acordo com as disponibilidades financeiras, bem como

(29). - Estatutos 16, 3. 
"aos prestimos do que foi a Ordem, e se pagou bem as obrigações della, em quando pôde" (30).

Tambem para a sepultura dos pobres havia as atenções do Carmo, mas não sem as reservas que lhe definem o espírito:

"Fallecendo algun Irmão pobre, que por cauza da sua nimia pobreza, se deve enterrar por conta da Meza, tocará o Ir. Procurador, fazer toda a diligencia se verdadeiramente carece de que a Meza o enterre; porq. muitas vezes tendo possibilidade, os seus herdeiros os querem enterrar como pobres" (31).

Em termo da Mesa de 1770 , registra-se outra função assistencial assumida pela Ordem Terceira do Carmo. Esta fez o papel de testamenteira e tutora da orfã Ana Francisca de Barros, filha de um Irmão do Carmo. As providências de praxe foram tomadas para a execução da vontade do defunto e da moça: procurou-se-lhe um marido e ela se casou com um carpinteiro.

Finalmente, lembramos aqui que a Ordem se preocupava de forma constante, em dar sepultura a todos os Irmãos. Se os sócios, arrebanhados no melhor meio da população, não necessitavam de maior assistência material, aspiravam ao repouso dos justos no Cemitério do Carmo. Disto a Ordem ocupava-se como uma obrigação e contava com a piedade, devoção e presença de todos os Irmãos.

Em geral, teve vida tranquila a veneravel Ordem do Carmo da Vila de São João del-Rei. As grandes batalhas judiciárias que envolveram outros sodalícios do Carmo, como os de Vila Rica, Vila do Carmo, Sabará e Diamantina, não são encontrados no de São João del-Rei. Mas, como grupo poderoso que era, reunindo uma elite ciosa de prerrogativas, tornava-se inevitavel a disputa e o choque com outras associações diferentes, com o poder civil e eclesiástico, em busca de maior autonomia e afirmação ou a procura, na rivalidade, do primeiro lugar.

As crises internas da Ordem do Carmo foram muito restritas, esporádicas apenas. Em termo de 1776, registra-se um protesto dos Irmãos Definidores, Tesoureiro e Procurador, sobre a precedência nos lugares da Mesa e atos públicos. Desconhecemos pormenores do incidente. Ao tratar de cada Irmão qualificado, o Estatuto tem o cuidado

(30). - Estatutos 15.

(31). - Estatutos 27, 5 . 
de fixar o seu lugar. Numa associação em que o indivíduo buscava projeção, era natural o protesto quando a mínima norma deixava de ser cumprida.

Crise mais séria, já no século XIX, deu-se quando um Padre Comissário não recebeu com agrado paternal admoestação do Padre Provincial Carmelita. Abandonando seu emprego, teve a solidariedade de toda a Mesa, que se demitiu. O Pe. José Maria Xavier, célebre musicista, benfeitor da Ordem e homem de grande virtude, contornou a situação, assumindo a direção da Ordem e recompondo a Mesa.

Foi em 1769 que a Veneravel Ordem do Carmo teve o seu primeiro atrito com outra agremiação, a importante Irmandade do Santíssimo Sacramento, que funcionava na Matriz do Pilar. Entendia a Irmandade ser seu direito comparecer sempre, "com opas e toxas", à exposição solene do Santíssimo Sacramento que se fazia durante a novena de Nossa Senhora do Carmo, como tambem na procissão que se fazia no dia de sua festa, quando saia, atrás do andor da Virgem, em reluzente custódia, a Sagrada Hóstia. Julgava assim a Irmandade porque no Carmo não se conservava o Santíssimo e era uma Capela dependente da Matriz. O suposto privilégio feriu os brios dos Irmãos do Carmo, que reagiram contra a abusiva intromissão da gente do Santíssimo. Atraves do Prior foi feita petição ao Bispo de Mariana, em longa exposição de motivos, para conservação do sacrário na Capela da Ordem. Com o consentimento do Ordinário e erigido canonicamente o sacrário, foi plena a vitória conseguida pelos Irmãos do Carmo.

Caminho para maior autonomia foi conseguido no mesmo ano de 1769 , com a provisão de sepulturas da Capela livres de qualquer pensão paga à fábrica da Matriz. Na petição feita à Diocese de Mariana, a Ordem menciona concessão idêntica feita às Irmandades de Santo Estevão e Santa Efigênia e conclui que, se às demais confrarias leigas, o direito o permite, com muito mais razão às Ordens Terceiras.

Sem dúvida, o atrito mais grave e de maior duração foi com a Ordem Terceira de São Francisco. Reunia a Ordem Seráfica gente do mesmo agrupamento social, idêntica à dos Irmãos do Carmo; era natural e mesmo inevitavel a rivalidade entre as duas agremiações. O pretexto foi a procissão de Corpus Christi, feita na Igreja da Matriz, no ano de 1774 . Tendo ambas as Ordens comparecido à solenidade, o Vigário da Vara concedeu precedência à Ordem Terceira de São Francisco. Foi um alvoroço entre os Irmãos do Carmo, seriamente ofendidos. Não se fez esperar o protesto encaminhado, por escrito, ao mesmo Vigário e assinado pela Mesa Administrativa, por ter este conferido 


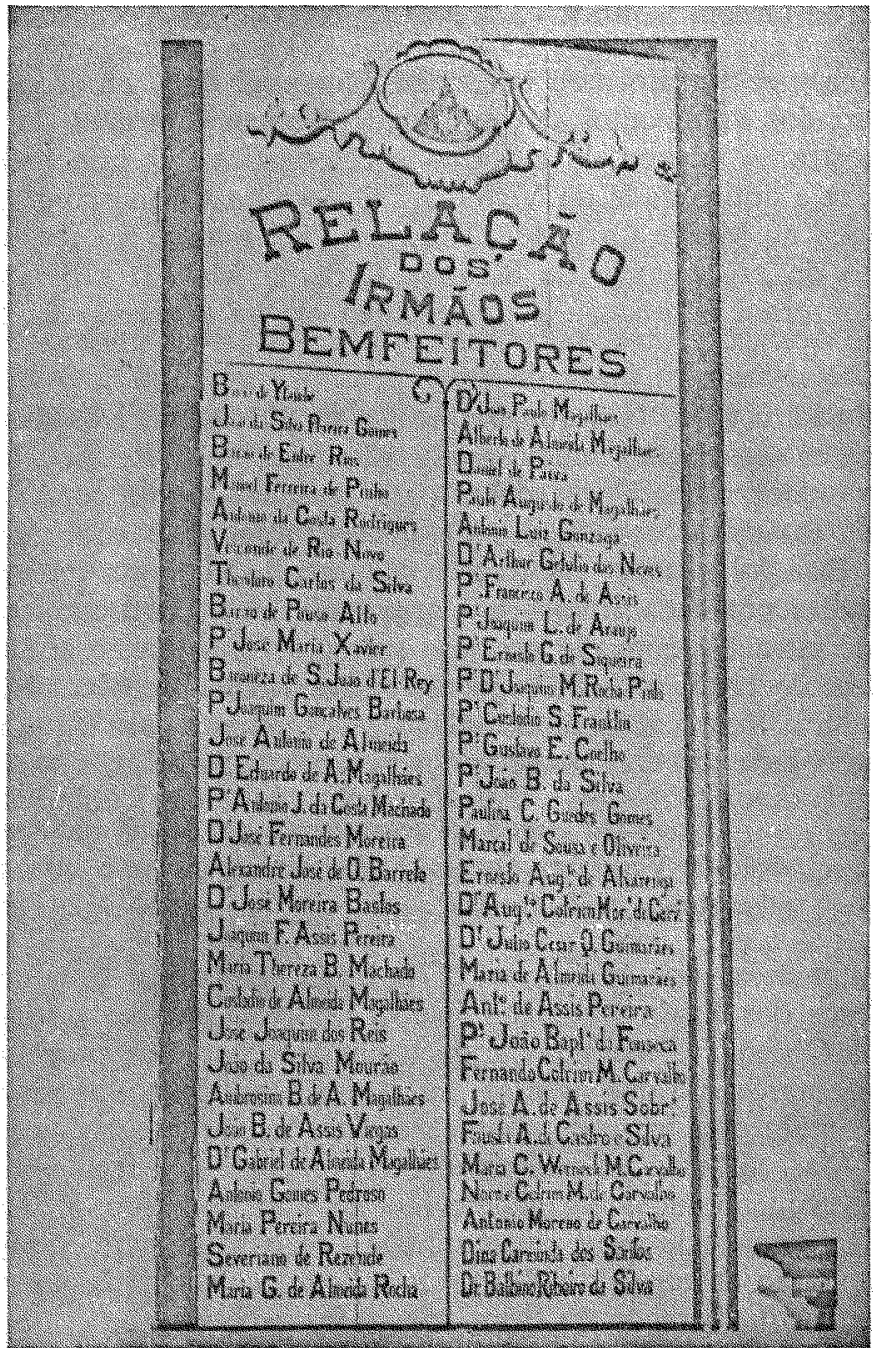

Fig. 3. - Relação dos Irmãos Benfeitores. Quadro localizado na Sacristia da Igreja do Carmo de São João del-Rei. 


\section{$-146-$ \\ "precedencia de primazia de ir na procissão de Corpus Christi"}

à veneravel Ordem Seráfica (32) .

O caso se transformou em longa demanda, onde eram gastos os mais variados argumentos de autoridade bíblicas e provas de direito para mostrar o engano da autoridade eclesiástica. O principal argumento era a antiguidade da Veneravel Ordem do Carmo com sua origem eliana no Monte Carmelo. Tudo em vão, porque foi reconhecido o direito de precedência da Seráfica Ordem. Mas, o sábio Vigário soube contornar a situação abrindo dupla ala na procissão de Corpus Christi.

Não foi o único fato que traduziu a rivalidade entre as duas mais importantes associações religiosas de São João del-Rei. Lutavam em recrutar maior número de sócios para crescimento de suas fileiras. Usavam, então, de expedientes de maiores ofertas e vantagens religiosas. Esta foi a razão em fixar o número de quarenta missas a serem rezadas por cada Irmão do Carmo falecido. Era uma segurança maior de salvação, com tão precioso sufrágio. E o que se lê em carta da Ordem de 1825, a Frei Diogo dos Anjos Rocha, Provincial Carmelita. Pedia a Mesa a redução do sufrágio de quarenta para trinta missas, pois estava havendo enorme acúmulo na celebração delas.

"Em outro tempo foi estabelecido por huma indiscreta opozição a Veneravel Ordem Franciscana para com este pretexto adquirirmos mais Irmãos".

Outra desavença surgiu em 1778, desta vez com a Irmandade do Bom Jesus dos Passos, que funcionava tambem na Igreja Matriz do Pilar. A Ordem recebeu convite da Irmandade para sua procissão, pedido de empréstimo dos ornatos dos Anjos e outras coisas mais. Era muito comum esta troca de gentilezas entre as várias associações religiosas. Mas, já havia um ressentimento por parte dos Irmãos do Carmo por pequeno incidente acontecido no ano anterior: E, agora, a coisa não tinha sido bem encaminhada. O convite para a procissão - "mandarão entregar por um preto" - foi considerada pouco caso e ofensa. A deliberação do Prior não se fez esperar:

"não vả no dia ao encontro da Procissão dos Passos".

(32). - Arq. da Ord. Terc. Doc. avulso. 
Tudo estava à disposição dos Passos: ornatos dos Anjos, alfaias e paramentos. Não o "acompanhamento desta Veneravel Ordem", porque, no ano anterior, tendo a Ordem comparecido, ficou em lugar impróprio e houve mesmo quem dissesse

\footnotetext{
"que os Irmãos desta Veneravel Ordem herão muito zelosos mas poucos puliticos".
}

Não permitindo semelhantes "desfeitos e descortejos", negava-se o Prior e a Mesa a "pôr sua procissão na rua". Tudo, entretanto, terminou aí mesmo. Nos outros anos, como mostram outros convites, as relações entre as duas corporações foram as melhores (33).

$\mathrm{O}$ comum, repetimos, era o bom relacionamento entre as várias confrarias. E inumera a correspondência entre os Terceiros do Carmo e outras Irmandades. Muito frequentemente eram trocados convites para as mais variadas festividades e procissões, pedidos de empréstimos ou agradecimentos de favores. Assim, em ofício de 11 de maio de 1837, o Provedor João Gonçalves Gomes, da Irmandade do Santíssimo Sacramento, agradecia ao Carmo a caridade do empréstimo de uma roda, que muito serviu para amassar as pedras com mais facilidade.

Com tanto desejo de autonomia e afirmação, teve a Ordem tambem seus problemas com as autoridades civis. Já em 1773, enviava a Ordem ao Rio de Janeiro, junto ao Superior Tribunal de Relação, seu Procurador, o Irmão João Cosme Rebello, para solucionar "importantes cauzas e dependencias". Não podemos precisar, por silêncio dos documentos, quais foram estas causas e quais as soluções dadas a elas.

Os maiores atritos, entretanto, são registrados à época do Império entre a direção da Ordem do Carmo e as autoridades da Província de Minas Gerais, mas todas sem maiores consequências.

Em outubro de 1835, o Presidente da Província, José Feliciano Pinto Coelho da Cunha, para satisfazer exigência da Assembléia Legislativa Provincial, encaminha ofício ao Sr. Juiz do Civil do Termo de São João del-Rei, para que este preste informações sobre as associações religiosas existentes na cidade. Pedia-se uma relação das Irmandades, Ordens Terceiras e Confrarias; cópia das resoluções de aprovação de seus Estatutos e Compromissos; rendimentos das mesmas e, finalmente, o levantamento do patrimônio de cada corporação. O Juiz encaminhou o pedido aos Irmãos do Carmo, como deverá ter feito a outros. A resposta da Veneravel Ordem Terceira do Carmo foi evasiva, transpirando evidente má vontade nas informações; e o mais sério: os dados apresentados, comparados a outros, não estavam exatos, demonstrando descuido claro em sua coleta.

(33). - L. de Termos e del. da mesa. 
Reação maior surgiu em 1858 , época em que o Governo Imperial intervinha abertamente nas Ordens Religiosas e, por extensão, nas Ordens Terceiras. O Governo Provincial exigia a prestação de contas da Ordem do Carmo. A Mesa Administrativa, em longa exposição de motivos, pede ao Dr. Juiz de Direito e Corregedor que torne sem efeito a notificação exigida. Em síntese, a Ordem defende a posse imemorial, sempre reconhecida, de não prestar contas a ninguem, a não ser às Administrações posteriores da mesma corporação, como aos Visitadores e Delegados eventuais do Provincial Carmelita. O Livro de Termos deixa de registrar a sequência dos fatos, não nos permitindo saber o resultado. Mas, reconhecemos a capacidade de resistência da poderosa Ordem em defender sua autonomia .

A promulgação do Código de Posturas, em 1887, fez surgir novo atrito com as autoridades civis, agora com a Câmara Municipal (34). A Ordem protestava contra os artigos 70 e 130, que feriam o Estatuto do Carmo. Salvando sua autonomia, não admitiam os Irmãos do Carmo a fiscalização municipal de seu sagrado cemitério nem renunciar aos continuados e costumados dobres de sino para os Irmãos falecidos. O assunto foi debatido e glosado pela Imprensa local e, logo depois, a República se encarregou de dar solução ao problema.

A associação do Carmo teve tambem a preocupação de se estender e controlar outros sodalícios como verdadeiras filiais. Para isto, considerava como Vice-Comissários os párocos das mais variadas regiōes, em lugares próximos ou extremamente longínquos. Exemplificando citamos aqui os seguintes lugares que dependiam do Carmo de São João del-Rei:

"S. Gonçalo da Campanha, Rio Verde, Rio do Peixe, Lavras, Dores, S. João Nepomuceno, S. Anna de Bamboi, Carrancas, Barbacena, Quillombo das Dores, Passa Tempo, S. Ritta do Rio Abaixo, Arraial da Oliveira, S. Antonio do Amparo, Bob Sucesso, S. Antonio da Alagoa dourada, Freguesia dos Prados, Furmiga".

Foi assim que viveu a veneravel sociedade da Penitência da Sempre Virgem Maria do Monte do Carmo. Era um grupo fechado que se projetava na vida da cidade. Como Irmão do Carmo, o homem se sentia realmente importante e tinha razões para isto. Branco de geração, rico, autônomo, escolhido entre muitos como de bons costumes, branco tambem na vida, era um indivíduo realizado de verdade. Pro-

(34). - Código de Posturas e Regimento Interno da Câmara Municipal de São João del-Rei. 
jetado na vida social de sua cidade era um deleite desfilar com a veste carmelita no caminhar das procissões. Seu bem-estar social se traduzia em participar daquela minoria sempre impermeavel à corrupção, gente de bem e que gozava do privilégio de frequentar luxuosa Igreja, ouvir boa música, entoar o Te Deum e escutar as sagradas palavras que encantam o espírito.

\section{* * \\ VIDA RELIGIOSA.}

Em vão, nos 35 capítulos das Atas, Leis e Estatutos da Veneravel Ordem Terceira da Penitência da Sempre Virgem Maria do Monte do Carmo, fomos procurar um capítulo específico que retratasse de forma profunda e clara, a espiritualidade e a ascese cristã.

A procura da perfeição e da própria santificação, na clássica definição da finalidade das Ordens Religiosas, Congregações, Ordens Terceiras e outras associações similares, que hoje encontramos sancionada no Código de Direito Canônico, está longe de ser encontrada no Compromisso dos Irmãos do Carmo. Somente de modo vago, transitório, em segundo plano, fala-se em atos caritativos ou pensa-se no mandamento novo da caridade, no "amai-vos uns aos outros" do Evangelho e nunca na instrução sólida e convicta dos Irmãos nos mistérios da fé, nos fundamentos do dogma católico, em sua rica universalidade para a solução de todos os problemas da vida do cristão.

Assim, ao tratar da autoridade maior, do Prior da Ordem, no Capítulo II pede o Estatuto que tal Irmão seja

"caritativo para se inclinarem ao bem das almas dos Irmãos defuntos, e ao remedio dos pobres" e ainda que uma vez "lidos os ditos Estatutos, admoestará o dito Prior a todos e a cada hum dos Irmãos, que com claridade e diligencia assistão a sua obrigação, e não faltem ao Serviço de Nosso Senhor, para que o dito Prior the dará todo o bom exemplo, sendo o primeiro em tudo" (1).

O mesmo se deixa transparecer - e aqui de forma mais agravante - quando o Estatuto regulamenta as obrigações do Padre Comissário, ao qual é entregue "toda a jurisdicção sobre o Espiritual" dos Irmãos. As obrigações ou "materias Espirituaes" definidas são as seguintes: aplicação, com toda a brevidade possivel, dos sufrágios aos Irmãos e Irmãs defuntos; cuidado na celebração das missas por inten-

(1). - Estatutos 2, 1-6. 
ção dos defuntos e outras de praxe da Ordem; vigilância, para que os Irmãos não faltem às confissões, comunhões, jejuns, disciplinas, orações mentais, lembrando a todos as penalidades previstas: lançamento, cumprindo todas as formalidades, do hábito de Irmão; atendimento às confissões dos enfermos; assistência aos enterros dos Irmãos; distribuição da Comunhão no segundo domingo de cada mês (são os dias de jubileu); e como última atribuição

"praticas Espiritual, expondo nellas a materias moral conducente, e importante a observancia da Regra e Estatutos della, reforma da vida, e salvação das almas dos nossos Irmãos, acabadas as Praticas, mandará feixar a porta da Capella ficando dentro todos os Irmãos em Comunidade, e ahi com caridade advertirá a todos as faltas em que tiverem cahido, e lhes dará por ellas aquellas penitencia saudavel, que the parecer, para que assim não faltem as suas obrigações" (2).

O Padre Comissário, o "Prelado Espiritual" da Ordem, ao qual os Irmãos Terceiros, debaixo do preceito formal e de obediência, em tudo o acima proposto, obedecerão, com submissão e sem réplica, em bem de suas almas e emenda de suas vidas.

Padre, pastor de almas - na melhor das exigências da moderna Pastoral - está o Comissário longe de cultivar e formar almas, mais preocupado com as letras de um regulamento que lhe é imposto e ao qual ele se sujeita porque quer sobreviver e gozar de uma associação em evidência.

O padre sempre se interessa mais pelas Irmandades, onde há mais conforto, são mais bem pagos, principalmente tratando-se do Carmo. A ocupação de ser Comissário, ser padre, cọmo observa Saint-Hilaire, é um meio de vida (3).

A formação dos iniciantes da Ordem, dos noviços, é entregue a um Mestre, que pode ser um sacerdote ou um leigo, dela não participando diretamente o Comissário. Mesmo que o fosse, não se procura tambem aqui uma base para uma profunda convicção cristã dos candidatos a Irmãos. As exigências da preparação do noviciado são formais, superficiais, como a instrução do Conhecimento das Regras ou Estatuto, os Santos Exercícios que a Veneravel Ordem tem e, na falta do noviço, a repreensão com caridade, prudência e afabilidade, a peni-

(2). - Estatutos 3 .

(3). - AUGUSTO DE SAINT-HILAIRE, Viagens pelas Provincias de Rio de Janeiro e Minas Gerais, p. 164. 
tência de acordo com a culpa da negligência. Terminados os onze meses de Noviciado, o requisito maior para a profissão é o conhecimento da Regra e ter o próprio hábito para os atos e funções públicas da Ordem (4).

Nenhum trabalho de catequese mais aprimorada para quem deseja aperfeiçoar sua vida cristã e ingressar numa Ordem Terceira.

Preocupa-se, pois, a Ordem apenas com as práticas exteriores, numa doutrinação de verniz, sem descer ao sentido das Escrituras, da moral cristã e ao conteudo dos Mistérios. E ainda Saint-Hilaire que observa ter os homens que povoavam o Brasil, uma idéia obscura e incompleta da religião cristã (5).

Com maior clareza a exterioridade religiosa se evidencia nas visitas de praxe feitas à Ordem, por patente do Padre Provincial Carmelita do Rio de Janeiro. Durante o século XVIII estas visitas ao Carmo de São João del-Rei foram muito frequentes, como facilmente se vê no Livro de Termos, onde estão registradas as patentes dos Visitadores, e os longos capítulos, onde eles apontam defeitos, corrigem, elogiam ou confirmam soluções. Estes capítulos são precedidos de preâmbulos, trazendo todos os títulos eclesiásticos do encarregado da visita. Assim, em 1778:

\footnotetext{
"Reverendo Licenciado em Artes Manoel Martins de Carvalho, Comissário do Santo Ofício e Vigário colado na Paroquial Igreja de Nossa Senhora da Conceição dos Prados, Visitador desta Veneravel Ordem". O de 1775: "O Rvmo Dr. Jullião da Silva e Abreu, Presbitero do habito de S. Pedro Nolasco, do Supremo Tribunal de Santa Inquisição, Vice Comissario Vizitador da Veneravel Ordem $3^{\text {a }}$ da Penitencia de Nossa Senhora do Monte do Carmo".
}

Fora o pitoresco, eram todos inquisidores, mas não podemos provar, pelo arquivo da Ordem, a existência de nenhum processo contra algum herege, cristão-novo ou homem ruim de costumes, infiltrado entre os Irmãos do Carmo.

O conteudo destas visitas é vazio de espiritualidade, no melhor estilo do catolicismo praticado pela Ordem. Assim, o Dr. José Sobral e Souza fala superficialmente, ou melhor, usa as palavras caridade, paz, concórdia, entendimento, perfeição que consiste "na visão que com

(4). - Estatutos 12, 6-7.

(5). - AUgUSTO DE SAINT-HILAIRE, ob. cit., p. 162. 
Deos devemos ter". Cita depois, de forma desordenada, São Paulo, São Mateus, São Bernardo e Santo Ambrósio. E esta a visita mais "espiritual" que achamos. Assim mesmo termina no formalismo em seus dois últimos capítulos, recomendando que os Irmãos e Irmãs que fizeram o noviciado e não professaram, só o poderão fazer na hora da morte com "avultada esmola a Ordem" e ainda proibindo o empréstimo, para fora da Vila, de qualquer coisa da igreja...

Outras visitas são mais formais ainda, recomendando livros para assentamentos de sepulturas, cuidado nas prestações de contas, maior ou menor pompa nas solenidades religiosas, guarda dos paramentos e alfaias. Houve tambem visitas incômodas que não agradaram. E o que acontece em 1772 com o Padre Antônio Duarte Pinto que, de modo incisivo, recriminava o excessivo uso de tochas nas procissões. Tanto gasto na distribuição de cera sem necessidade, no entender do Padre Antônio, deveria ser empregado no erário da Ordem. Com esta decisão não concordou a Mesa que, não querendo ver diminuido o esplendor das procissões, recorre ao Provincial Frei Bernardo de Vasconcellos. Este, imediatamente, concede a petição, pois,

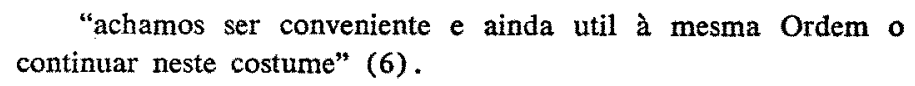

"achamos ser conveniente e ainda util à mesma Ordem o continuar neste costume" (6).

Temia-se a morte, suas consequências, a vida do alem, o juizo vingador. Uma religião de medo e não de participação, de morte e não de vida. No Estatuto do Carmo, ainda no preâmbulo, há a ameaça. Lembra a

\begin{abstract}
"vigilancia sobre a exata observancia das ditas Leys" e adverte que "toda a relaxação, que sua culpa, e negligencia nellas houver, dara extreitissima conta ao Suprêmo Juiz Christo Jezus, naquelle ultimo e formidavel dia de Juizo".
\end{abstract}

Revestia-se de enorme preocupação a passagem desta vida. Procurava-se mesmo ingresso na Ordem pensando-se na salvação que seria conseguida com uma série de práticas religiosas exigidas na Regra, com a Confissão aos ouvidos do Padre Comissário - "morriam todos arrependidos", diz João Camilo de Oliveira Tôrres (7) — do Viático levado em procissão até sua casa. O complemento era a exé-

(6). - L. de Termos e del. da mesa.

(7). - JOÃO CAMILO DE OLIVEIRA TÔRRES, História de Minas Gerais, vol. III, p. 630 . 
quia, na colocação do caixão aberto na eça localizada na nave da igreja, rodeada de velas de cera que se consomem iluminando o recital do Requiem, do De profundis, do Dies irae, com o sacerdote vestido de capa preta, em inúmeros asperges, naquela atmosfera triste e incômoda de cheiro de incenso. Tudo isto aumentando a dor, amargurando a assistência e os parentes já apressadamente vestidos de preto, num doce masoquismo. Ritual que a todos deprime e infunde enorme tristeza e angústia. Depois o acompanhamento em fila até ao cemitério, o dobre rouco do sino, o encerramento na sepultura.

Procurava-se a Ordem para gozo deste ritual, garantia de sepultura na paz do jazigo e ganhar os sufrágios de missas e missas na esperança da clemência divina. Aí estava a obrigação da prática da caridade na exigência de seu Compromisso:

"todo o Irmẫo que fallecer, e quizer ser enterrado nos jazigos da Ordem, se lhe dará nelles sepultura na parte onde houver lugar, e será accompanhado com todos os Irmãos que nestes actos mostrarăo a sua caridade, não faltando a elles, salvo estiverem legitimamente impedidos, pela alma de qualquer Irmão, ou Irmã $3^{a}$, será obrigada a Meza a mandar com toda a brevidade dizer-lhe as Missas costumadas, e mais que até ao presente se praticou" (8).

Para as sepulturas foi construido o cemitério da Ordem, ao lado da Igreja, em muro alto, com artístico portão de ferro, feito em 1836, pelo ferreiro Jesuino José Ferreira. A solidez do cemitério, com as sepulturas em gavetas, as lajes em mármore no pátio interno, a limpeza dos pórticos e corredores, ainda impressionam hoje e fazem lembrar o culto dos Irmãos do Carmo aos mortos.

Se há sufrágios individuais após a morte de cada Irmão, há tambem os sufrágios coletivos estabelecidos pelo Estatuto, em dia próprio e fora da data tradicional de Finados. Todo o rito está fixado no Capítulo XXXIV e lembrado muitas vezes no Lovro de Termos. As comemorações de sufrágios iniciavam à tarde do dia de Santo André Apóstolo, com Matinas de Nove Lições, Laudes e Vésperas, tudo com ofício solene, com acompanhamento de orgão ou do canto gregoriano. No outro dia se cantava a missa de paramentos pretos, havia Sermão fúnebre por conta da Ordem e, no final da cerimônia, o canto do "Memento" com eça ou pano preto, asperges e incenso. E como obrigação, estavam lá todos os Irmãos.

(8). - Estatutos 27, 1. 
Uma palavra ainda sobre os sufrágios é acerca das missas a dizer para cada Irmão defunto. Inicialmente em número de 30 , depois 40 - nos bons tempos do ouro - e a volta para 30. Estas missas ditas em particular pelo Comissário eram em seguida e sem interrupção uma gregoriana na linguagem eclesiástica - iniciadas logo após a sepultura. Ocorrendo o acúmulo delas em decorrência do número de mortos sucessivos, a Ordem viu-se obrigada a mandar reza-las fora. Importâncias, então, eram enviadas ao Rio de Janeiro, a outros conventos e até a Portugal, para que se cúmprisse com rigor a exigência do sagrado ato do sufrágio.

Mas, características outras vão definir o comportamento social da Ordem do Carmo, diante do ideal religioso, muito ao feitio da época . Foram as solenidades religiosas, a pompa, o esplendor das procissões, o trato com a igreja, com os altares, santos e paramentos, a evocação à Virgem Santíssima Mãe Nossa, o culto divino que fizeram a essência da vida espiritual e social desta corporação em festa. Tal procedimento serve como amostra da "ocorrência de uma idade barroca mineira" ou "projeção do mundo barroco" ou ainda resultado de um "íntimo e grato sentimento de uma população privilegiada pela opulência das riquezas", tudo como quer Affonso Ávila (9).

As principais festividades da Ordem estão concentradas na celebração da festa de Nossa Senhora do Carmo, como padroeira, as comemorações feitas durante as Sextas-Feiras da Quaresma em memória dos Passos da Sagrada Paixão de Cristo e a grande procissão do Enterro na Sexta-Feira Maior.

Mas, não se contentou o Carmo apenas com o "luzimento de tão piedosos actos" (10). Outras festas e louváveis exercícios eram realizados em honra de São Brás, Santo Amaro, Santa Luzia e da grande Santa Teresa e fazia-se a procissão da "Razoura" com a imagem de Nossa Senhora e de Santo Elias. Estes são os "Actos do Culto Publico que nella se celebrão" como se lê em carta a Frei Luiz de Santa Bárbara, datada de 1855, quando Provincial Carmelita pedia à Mesa esclarecimentos com finalidades estatísticas.

Havia ainda os atos religiosos extraordinários em épocas especiais. Em 1850 encontramos o registro de sermão de preces e procissão de penitência em razão de uma peste, que desconhecemos qual seja.

(9). - AFFonSO ÁILA, Residuos Seiscentistas em Minas, p. 8.

(10). - Estatutos 32 . 


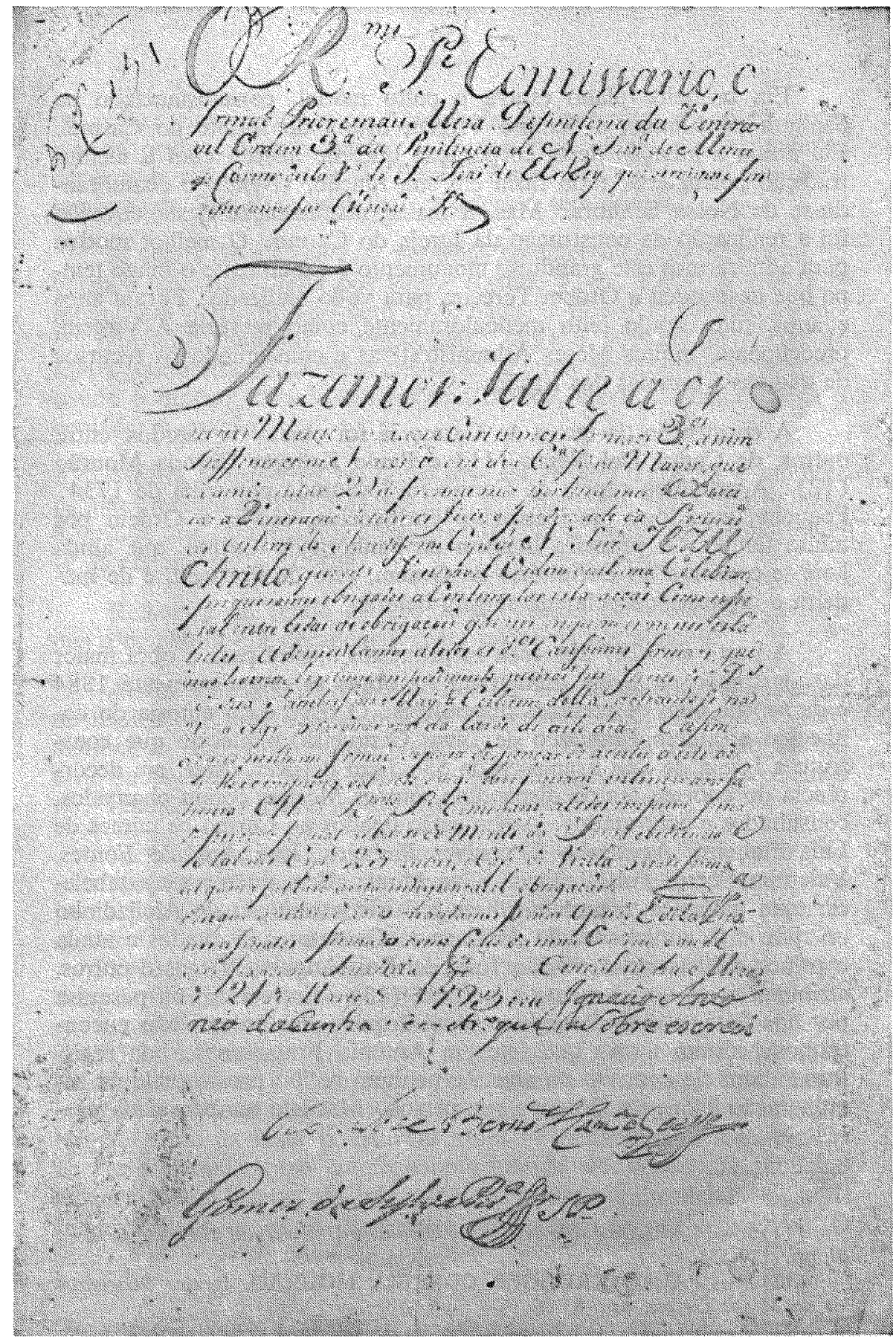

Fig. 4. - Convite da Mesa para a Procissão de Sexta-Feira Santa. Documento avulso do Arquivo da Ordem. 
Em primeiro plano estava o culto marial, consubstanciado na Senhora do Líbano, a Sempre Virgem Maria do Monte do Carmo. Ela atraia a atenção desta corporação que, de acordo com a melhor tradição portuguesa, tudo fazia em sua função, vivendo e enamorando-se de Nossa Senhora. Mas, a maior manifestação desta devoção foi a realização da construção da Igreja do Carmo. O melhor motivo para admirarmos este grandioso monumento é exatamente o longo tempo que despendeu a Ordem Terceira para ve-lo realizado. Foram anos e anos, tudo sendo feito meticulosamente como merecia a Virgem, preocupando muitas Mesas Administrativas e consumindo os recursos de dádivas e esmolas dos Irmãos.

A construção da igreja do Carmo já foi objeto de estudos, entre outros, de Carlos Del Negro (11) e Paulo Krügger Correia Mourão (12). A primitiva capela do Carmo foi levantada por volta de 1734 . Pequena, mas logo preciosamente enriquecida, serviu à Ordem por muito tempo. A primeira imagem da Senhora do Carmo, que ainda hoje se conserva no Definitório da Ordem, veio de Portugal, é de madeira e impressiona pela sua singela beleza.

A partir de 1787 apareceu os primeiros ajustes para a obra maior da construção da igreja definitiva. As obras se estenderam até 1884 e de acordo com os recursos disponíveis. O risco é da autoria do conhecido arquiteto Francisco de Lima Cerqueira, o mesmo que construiu a Igreja de São Francisco de São João del-Rei. Mas, em decor-' rência do enorme tempo dispendido, outros Mestres foram chamados, consultados e contratados. Assim estão ligados ao Carmo os nomes de Luis Pinheiro, Agostinho Gonçalves Pinheiro, José Antônio Fontes, Valentim Correa Pais, João da Silva Muniz. Sem querermos estabelecer uma polêmica, é bastante discutivel a contribuição do Aleijadinho no risco e na ornamentação do Carmo. Os autores já citados e ainda o principal historiador de São João del-Rei, Augusto Viegas e outros, atribuem a ele notadamente a portada (13). Entretanto, na pesquisa por nós feita, e considerando o atual arquivo da Ordem, não encontramos nenhum termo que fale em Antônio Francisco Lisboa registrando com ele contrato ou ajuste e nenhum recibo prova qualquer remuneração feita pela Ordem a sua pessoa. Mas isto tambem nada pro-

(11). - CARLOS DEL NEGRO, Escultura Ornamental Barroca do Brasil, pp. 137-153.

(12). - PAULO KRUGGER CORREIA MOURÄO, Igrejas Seiscentistas de Minas Gerais, pp. 83-86.

(13) . - AUGUSTO VIEGAS, Notícia de São João del-Rei, pp. 203-206. 
va, pois, o risco pode ser do Aleijadinho e o arremate de outro, como era de praxe. A semelhança de riscos com outros do Aleijadinho decorre da influência dele em Francisco de Lima Cerqueira que viveu tambem em Vila Rica, mas the era inferior, sem dúvida.

A Igreja do Carmo está naquelas características da descrição do barroco em Minas, feita por Roger Bastide (14) . Leve, singela, formosa, com o frontispício bem trabalhado, o florão recortado, as torres oitavadas "vistosas e engraçadas" (15) e o resto do corpo da Igreja assobradado. A ornamentação interna é agradavel, predominando o branco sobre o ouro e sem dúvida, eleva a alma e chega a convidar à oração.

Mostra a Igreja os melhores dias da Ordem Terceira e tambem os maus tempos do empobrecimento. Internamente, sente-se a pobreza à medida que caminhamos do altar-mor para a saida. O mesmo ainda se dá em sua parte externa.

Reflete-se na Igreja do Carmo a situação econômica da Ordem que a construiu e a decadência desta poderosa corporação.

Assim edificada, com esforço dos Irmãos do Carmo, foi ela palco de realizações litúrgicas grandiosas do culto devido à Senhora Mãe Santíssima. Inúmeros termos registram as festas da Virgem do Carmo e de Santa Teresa. Estas narrações estão longe dos modelos célebres do "Triunfo Eucarístico" e do "Âureo Trono".

As narrações do Carmo são modestas, acanhadas, sem a linguagem "preciosa e rebuscada" de Simeão Fereira Machado. Mas a pompa existiu nestas solenidades religiosas que manifestavam o procedimento e a satisfação de sucesso daquela elite social da Vila de São João del-Rei. Tudo se fazia de acordo com o belo da época. A Igreja bem iluminada, as peças litúrgicas de ouro e prata, os paramentos ricos, as alfaias cuidadas. A festa de Nossa Senhora do Carmo era precedida da novena em longa preparação. Cantavam-se Matinas, Laudes, Vésperas e Completas, com música e sermão, ladainhas e orações, Te Deum seguindo-se a Benção do Santíssimo Sacramento. No dia exato da festa lá estavam todos os Irmãos, com suas túnicas de cor marrom e capa creme para a grande solenidade. O principal ato era Missa Solene, de três padres de casula e tunicelas. $O$ celebrante cantava a missa com acompanhamento de orgão e coro. $\mathrm{O}$

(14). - ROGER BASTIDE, Brasil, terra de contrastes, pp. 114-115.

(15). - L. de Termos e del. da mesa. 
Gloria in excelsis Deo era comemorado ao som de campainhas, orgão e repiques festivos de sino. Após o Evangelho, se fazia a homília da Virgem, por bom pregador, contratado com bastante antecedência, como exigia o Estatuto, que, em linguagem bacharelesca, discorria sobre as virtudes da Mãe Santíssima. À tarde havia procissão em que carregavam Nossa Senhora do Carmo em bem ornamentado andor, - Santíssimo Sacramento em reluzante custódia, com música, cantos, ladainhas, rezas e tochas.

Estava ai, anualmente, a festa de Nossa Senhora do Carmo ao lembrar, em miniatura, as grandes realizações do "Áureo Trono" e do "Triunfo Eucarístico", com o mesmo espírito de fé barroca e exemplo de mentalidade da cristandade das Minas. Na observação de Roger Bastide, tudo isto era símbolo não de maior intensidade da fé verdadeira, mas de um exito mais seguro da sociedade ambiente. $O$ poder religioso era o reflexo do poder social.

Cabe uma palavra importante sobre a música na Ordem Terceira do Carmo. Era evidente que recorresse à música de boa qualidade aquela gente que procurava sua Igreja tambem para o deleite. São João del-Rei, em sua ótima tradição musical, produziu músicos do melhor gosto artístico. Encontramos, no longo calendário repleto de música sacra, onde se juntavam as partes vocais às instrumentais, nomes e nomes de bons músicos contratados para as inúmeras festividades carmelitas.

Colhemos entre os recibos, alguns de pagamento a diretores de "múzica" e organistas como: Francisco Martiniano de Paula, Luiz Batista Lopes, "genial centelha de musicista", "distinto representante da sublime arte da música", José Maximiliano de Santa Anna, Antônio José de Souza Machado, Francisco José das Chagas "que se achava na direção da orquestra depois denominada Ribeiro Bastos", Francisco de Paula Miranda "da genial estirpe artística dos Mirandas", que, com Hermenegildo de Souza Trindade e Luiz Batista Lopes, pertenceu às raizes da orquestra Lira Sanjoanense e o notavel Padre José Maria Xavier que

"se consagrou inteiramente ao exercício de seu alto ministério e às inefáveis harmonias da música sacra, que seu gênio de compositor inspirado, fervorosamente cultivou" (16).

(16). - VIEGAS,ob. cit., pp. 70-72. 


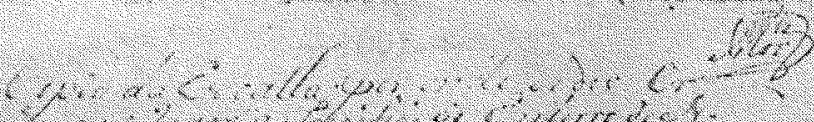

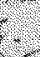

(2)

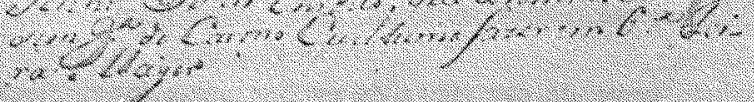

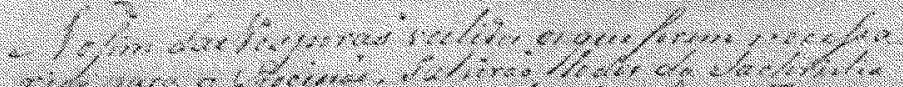

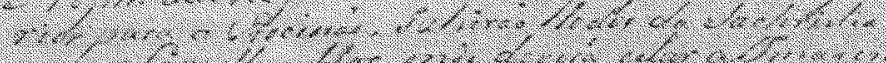

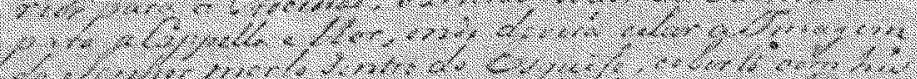

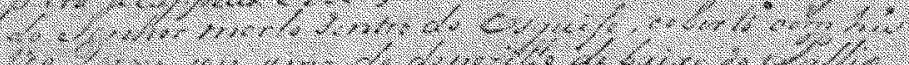

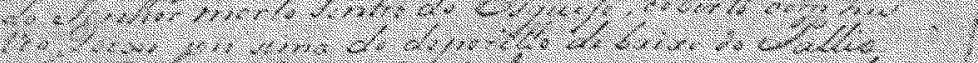

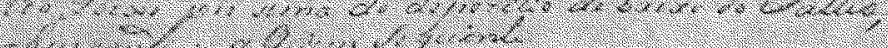

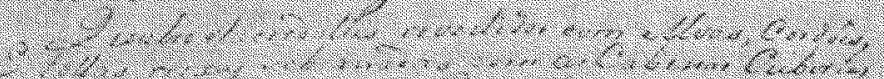

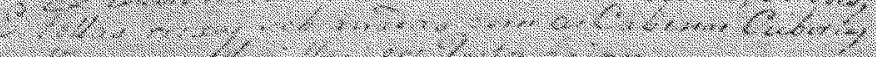

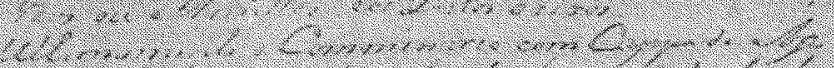

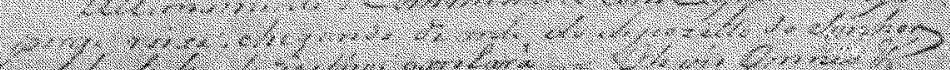

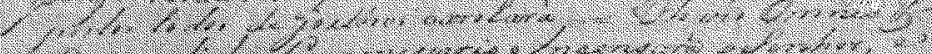
2.

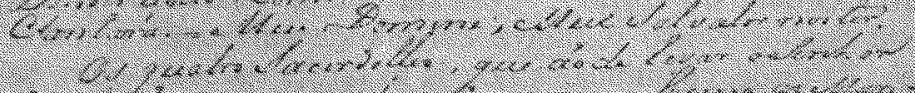

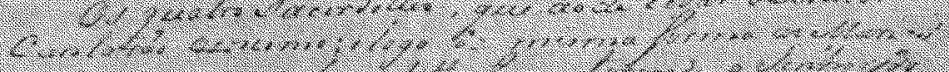
2.

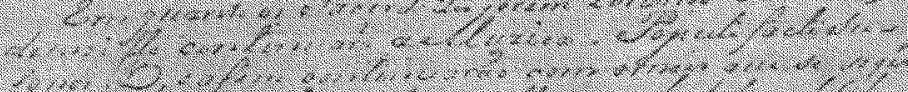
-

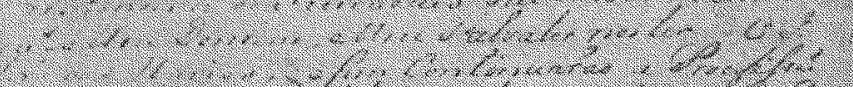

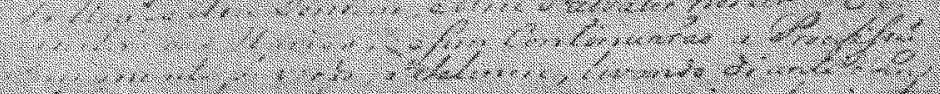
P.

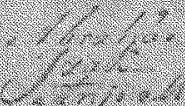

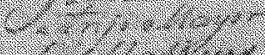 \\ -

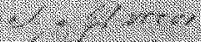

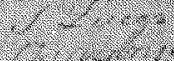

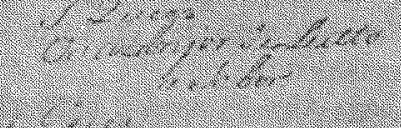

(2)

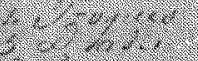

(2)

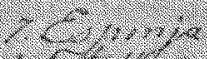

$1+2+2+2+2$

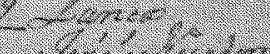

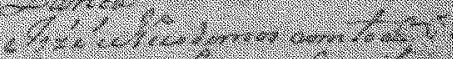

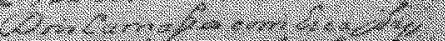

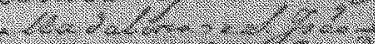

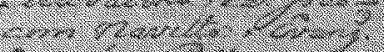

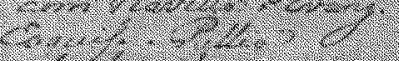

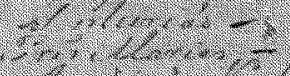

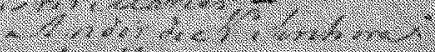

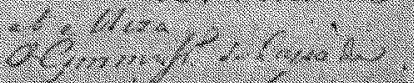

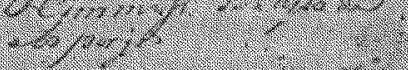

- 
Não pudemos verificar, se, como em outros grandes centros artísticos de Minas, eram eles mulatos, essa

"gente de cor capaz de evoluir até a interpretação de obras de alto nivel universal" (17).

Agora, as comemorações da Quaresma e da Semana Santa. A Ordem Terceira do Carmo de São João del-Rei deixava de cumprir - Capítulo XXXII de seu Estatuto, uma vez que a celebração dos Passos da Paixão de Cristo pelas ruas da cidade era privilégio de outra Irmandade, a dos Passos, da mesma paróquia do Pilar. Mas esta, com o requinte de bom serviço de relações públicas, não deixava de convidar à Veneravel Ordem do Carmo, e a ato tão piedoso não faltava a presença dos Irmãos Carmelitas.

Entretanto, a Procissão da Sexta-Feira Maior era privilégio da Veneravel Ordem do Carmo. Como a solene procissão do Enterro de Cristo Senhor Nosso resultava em grande edificação a todos, era obrigação da Orđem continuar a faze-la às tardes da Sexta-Feira Santa . Esta era a prescrição do Capítulo XXXIII do Estatuto, que desce aos pormenores de como devia andar a procissão. Encontramos, todavia, uma descrição mais curiosa e particularizada desta procissão, registrada no Livro de Termos e Deliberações, em 1825, aproximadamente e que não consta do Estatuto:

"Cópia da Escalla por onde se deve ordenar e reger a procipção do Enterro de Nosso Senhor Jesus Christo, que a Veneravel Ordem $3^{\mathrm{a}}$ do Carmo costuma fazer em $6^{\mathrm{a}}$ Feira Mayor.

No fim das Vesperas vestidos os que forem necessarios para a Procissão partirão todos da Sachristia para a Cappela Mor, onde devem estar a Imagem do Senhor morto dentro do Esquife, coberto com hu veo baixo por sima do depozitto de baixo do Pallio, observando-se a Ordem seguinte:

Quatro sacerdottes revestidos com Alvas, Cordōes, e Estollas roixas sobrassadas com as Cabessa Cubertas com veos ou Amittos eos Rostos baixos.

Ultimamente o Commissario com cappa de Azperge roixa, chegando diante do depozitto do Senhor postos todos de joelhos cantará $=$ oh vós omnes. Depois disto o Commissario Incensarão

(17). - FRANCISCO CURT LANGE, $A$ música Barroca (in "História Geral da Civilização Brasileira"), vol. II, p. 139. 
- Senhor, e cantará $=$ Meu Domine, Meu salvator noster. Os quatro sacerdottes, queão de levar o Senhor cantarão o mesmo e logo da mesma as Marias.

Em quanto os Sacerdottes forem tirando o Senhor do depozitto continuará de Muzica $=$ Populi facti Sumos easim continuarão como mais que se segue ao que responderão os Sacerdottes que levão o Senhor $=$ Meu Meu Domine, Meu Salvator noster $=0$ que repetirá as Marias, easin continuarão a Procipção com muita devoção, e Silencio, levando diante o Pindão baixo, logo aérus, e o mais da maneira seguinte.

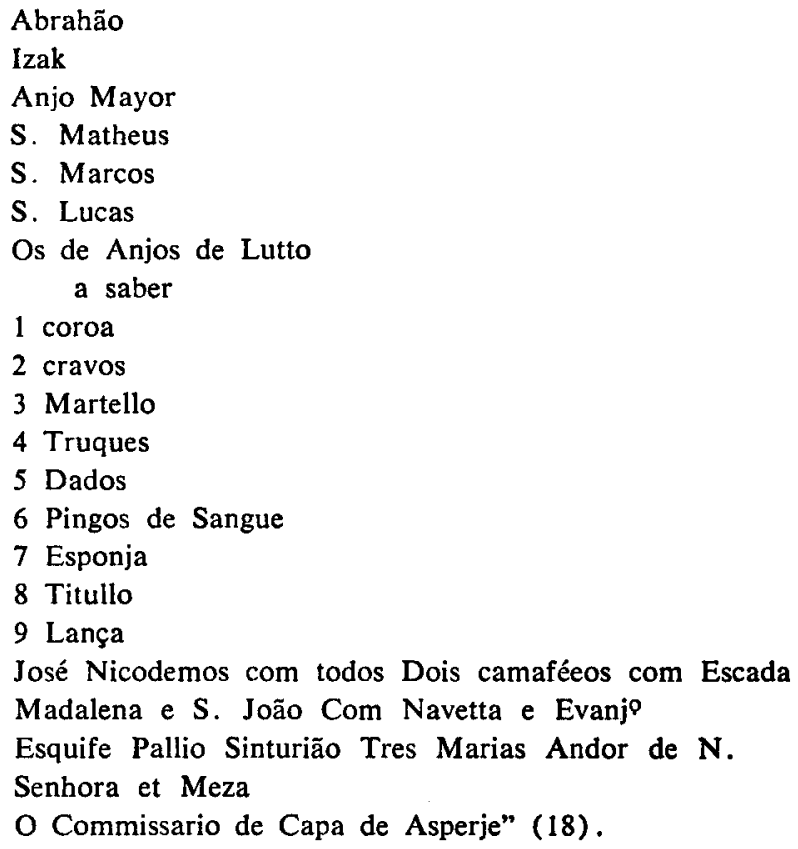

Muito parecida com esta descrição é a de Saint-Hilaire da procissão das Cinzas, feita pela Ordem de São Francisco na mesma cidade de São João del-Rei e que ele chama de

"cerimônia irreverente, em que ridículas momices se associavam ao que a religião católica tem de mais respeitavel" (19).

(18). - L. de Termos e del. da mesa.

(19). - AUGUSTO DE SAINT-HILAIRE. Viagem às nascentes do Rio São Francisco e pela Provírcia de Goyaz, pp. 98-100. 
A crítica convem de forma identica à Procissão do Enterro feita pela Ordem do Carmo. Está nela espelhada toda a mentalidade religiosa dos Irmãos Carmelitas. E uma cerimonia triste, no esquife do Senhor Morto, nas chorosas Marias, e na imagem da Virgem que saia às ruas com o rosto pálido e olhos esbugalhados, vestida de preto, imprimindo mais medo que piedade. E o retrato da preocupação constante com o alem, que levava o indivíduo a ingressar na Ordem a fim de se preparar, em vida, para a sepultura.

Procissão confusa, que junta personagens do Velho e Novo Testamento, que fala de anjos de luto carregando coroa de espinhos, cravos, martelo e pingos de sangue. Cerimônia realmente extravagante onde se fala o latim litúrgico de forma inadequada e onde os sacerdotes de cabeças baixas - vítimas da submissão - tudo ouvem e vêem em silêncio.

Está com a razão o articulista do jornal da cidade de São João del-Rei, $\boldsymbol{A}$ Tribuna, que assina com o provinciano pseudônimo de João Revoada, quando, em 1914, vê o fim do "Carnaval Religioso":

"Năo por economia, como parece ao articulista, tomou a Ordem do Carmo, a resolução de suprimir na imponente procissão o ridículo figurado, anacrônico, que desperta a risota em vez de edificar e comover".

Não deixamos de atender à lição de Thales de Azevedo quando fugimos ao aspecto do pitoresco e do depreciativo (20). Concluimos tambem que, na procissão do Enterro da Sexta-Feira Maior, realizada pela importante Ordem do Carmo, não deixa esta corporação de retratar, a sua maneira, seu comportamento social numa crença vigorosa, no valor para a Redenção da morte de Cristo.

Terminamos o capítulo lembrando a religiosidade dos Terceiros do Carmo no trato com o culto, santos e imagens. Fora as doações de altares do Visconde do Rio Novo e do Barão de Itambé, encontramos outras que mostram grande intimidade fazendo da Virgem "coisa nossa", vestindo-a e embelezando-a. Assim é atribuida à generosidade do Barão de Itambé os olhos de vidro para a imagem de Nossa Senhora do Carmo; o oratório pintado e dourado, com portas de vidro, onde se acha a Senhora resguardada do pó e da fumaça das velas com toda a decência, e ainda o vestido, o escapulário, e a capa de veludo bordada com fio de ouro. Temos aí o exemplo de um "culto sem obrigações e sem rigor, intimista e familiar" na caracterização feita por Sérgio

(20). - THALES DE AZEVEDO, O Catolicismo no Brasil, p. 7. 
Buarque de Holanda e

"que corrompeu, pela base, o nosso sentimento religioso" (21).

A religiosidade do Carmo não foge ao quadro geral apresentado pelo autor de Raizes do Brasil: religiosidade de superfície, atenta ao colorido das cerimônias, à pompa exterior, apagada ao concreto em total incompreensão da verdadeira espiritualidade. Uma religião de formas e não de conduta. Foi um bacharelismo transferido para o campo religioso.

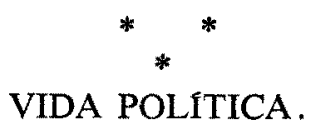

Quando pensamos em inicia resta pesquisa sobre a Ordem Terceira de Nossa Senhora do Carmo, localizada na importante cidade de São João del-Rei, era nossa intenção primordial mostrar a influência desta associação, enquanto associação, nos principais movimentos políticos das Minas e mesmo nacionais.

Sendo uma das mais célebres cidades mineiras, São João del-Rei teve notavel participação na História Política de Minas Gerais, contribuindo efetivamente para vários acontecimentos. Podemos citar aqui o episódio dos Emboabas, quando importantes lutas ocorreram em território sanjoanense, às margens do Rio das Mortes. O heroi da Inconfidência tem sua vida ligada a São João del-Rei. À Independência a cidade emprestou sua total cobertura, quando a 21 de abril recebeu a visita do Príncipe Dom Pedro. A Abdicação encontrou por parte do deputado sanjoanense, P. Custódio Dias, a redação de importante representação a Dom Pedro I, a 18 de março de 1831, e que tanto significou naquele momento. Funcionou em São João del-Rei, desde 2 de outubro de 1831, a Sociedade Defensora da Liberdade e da Independência Nacional, associação filiada à de igual nome, fundada no Rio de Janeiro por Evaristo da Veiga. Decisiva foi a contribuição de São João del-Rei durante a sedição militar de Ouro Preto, quando, por iniciativa da Câmara Municipal, Bernardo Pereira de Vasconcelos restaurou na Vila o governo legal, devolvendo-o logo ao Presidente Manuel Inácio de Melo e Souza. Foi ainda São João del-Rei sede do governo revolucionário em 1842, quando José Feliciano Pinto Coelho da Cunha assumiu a direção da cidade. Lembramos ainda o entusiasmo com que os filhos de São João del-Rei foram levados a participar nas lutas da Guerra do Paraguai (1). -108 .

(21) . - SERGIO BUARQUE DE HOLANDA, Raizes do Brasil, pp. 107(1). - VIEGAS, ob. cit., pp. 121-132. 
Assim, pensávamos ver na Veneravel Ordem do Carmo, que reunia altos dignitários da cidade, uma associação tambem política, contribuindo para decisões em várias oportunidades. Foi um engano. Examinamos, com extremo cuidado, todas as atas registradas nos Livros de Termos e Deliberações da Mesa, assim como todos os outros documentos do arquivo, à procura de dados que comprovassem a participação direta da Ordem nos acontecimentos políticos. Maior cuidado tivemos com as datas da Inconfidência Mineira, da vinda do Príncipe Regente Dom João, da Independência, da Abdicação, da Sedição de Vila Rica, da Revolução Liberal, das lutas externas do Segundo Reinado e da República. Entretanto, nada encontramos que comprove ter sido a Ordem, através de seu Definitório, um orgão de elaboração de planos e decisões políticas, à semelhança das lojas e oficinas maçônicas, como mostra nossa historiografia.

Nos seus termos, apenas uma vez, por ocasião da Sedição Militar de Ouro Preto, a Ordem lembra a situação política, quando explica a não realização da Procissão do Enterro, porque "agitada estava a Vila".

Mas, políticos foram mutios Irmãos do Carmo, membros da Mesa, que participaram ativamente na vida política local e mesmo nacional. A comprovação pode ser feita pelas assinaturas dos Irmãos que funcionaram no Definitório da Ordem, pela relação de nomes de pessoas que serviram à Administração Municipal de São João del-Rei, desde 1714. Entre os oito Vereadores que serviam à Câmara durante a Revolução Liberal, e que, por Decreto do Governo do Império de 30 de dezembro de 1841 , foram suspensos de suas funções, podemos identificar três Irmãos do Carmo: Joaquim José de Oliveira Mafra, Luiz Alves de Magalhães e José Maximiano Batista Machado. Ao mesmo tempo, foi o Irmão do Carmo João Gonçalves Gomes que recebeu do governo legal a incumbência de reorganizar nova Câmara $\mathrm{Mu}$ nicipal.

Políticos foram ainda o Juiz - termo equivalente a Prior, Provedor - Capitão Pedro da Silva Gomes, o Comissário José Lameda de Oliveira e o benfeitor da Ordem, Severiano de Resende.

A Ordem do Carmo, como expressão social de gente importante, servia, evidentemente, de veiculo para projetar na vida pública os seus membros. Mas, em suas reuniões, esta não aparece como orgão de deliberações políticas.

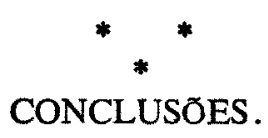

1. - A Ordem do Carmo, como assuciação rica, sem a preocupação de estabelecer uma base patrimonial e com a contribuição dos 
Irmãos, esbanjou luxo e, como boa empresa, soube oferecer bons empregos.

2. - A Ordem do Carmo foi uma corporação de homens brancos e ricos, recrutados na elite sanjoanense, representando um esforço na conservação dos bons costumes. Ser Irmão do Carmo era uma realização social.

3. - A vida religiosa da Ordem do Carmo é um excelente exemplo do Catolicismo brasileiro. Religiosidade de superfície, de manifestações exteriores e de festas, onde transparecia enorme preocupação com a morte.

4. - As reuniões da Mesa não deixam transpirar a ação da Ordem do Carmo como orgão de deliberações políticas.

\section{BIBLIOGRAFIA.}

ÁVILA (Affonso). - Resíduos Seiscentistas em Minas. Belo Horizonte. Centro de Estudos Mineiros. 1967.

AZEVEDO (Thales de). - O Catolicismo no Brasil. Rio de Janeiro. D. de Imprensa Nacional. 1955.

BASTIDE (Roger). - Brasil, terra de contrastes. São Paulo. Difusão Européia do Livro. 1959.

CARRATO (José Ferreira). - As Minas Gerais e os Primórdios do Caraça. São Paulo. Comnanhia Editora Nacional. 1963.

CINTRA (Sebastião de Oliveira). - Efemérides de São João del-Rei. Juiz de Fora. Esdeva. 1967.

DEL NEGRO (Carlos). - Escultura Ornamental Barroca do Brasil. Rio de Janeiro. Edições Arquitetura. 1961.

HOLANDA (Ś́rgio Buarque de). - A herança colonial (in "História Geral da Civilização Brasileira"). São Paulo. Difusão Européia do Livro. 1962. T. II. V. 1.

HOLANDA (Ś́rgio Buarque de). - Raizes do Brasil. Rio de Janeiro. Livraria José Olympio Editora. 1936.

LANGE (Francisco Curt). - A música barroca (in "História Geral da Civilização Brasileira"). São Paulo. Difusão Européia do Livro. 1960. T. I. V. 2.

MARIA (Padre Júlio). - O Catolicismo no Brasil (Memória histórica). Rio de Janeiro. Livraria Agir Editora. 1950.

MENEZES (Furtado de). - Clero Mineiro. Rio de Janeiro. Tipografia Americana. 1933.

MOURÃo (Paulo Krïger Corrêa). - Igrejas Seiscentistas de Minas Gerais. Belo Horizonte. Imprensa Oficial. ( $\mathrm{s} / \mathrm{d}$ ). 
PASSOS (Zoroastro Vianna). - Em torno da História de Sabará. Rio de Janeiro, S.P.H.A.N., 1940.

SAINT-HILAIRE (Augusto de). - Viagem às nascentes do Rio São Francisco e pela provincia de Goyaz.

SAINT-HILAIRE (Augusto de). - Viagem pelas Provincias do Rio de Janeiro e Minas Gerais. São Paulo. Companhia Editora Nacional. 1938.

SALLES (Fritz Teixeira de). - Associaçóes Religiosas no Ciclo do Ouro. Belo Horizonte, U. M. G., 1963.

SANTOS (Lúcio José dos). - A Inconfidência Mineira (Papel de Tiradentes na Inconfidência Mineira). São Paulo. E. P. Liceu Coração de Jesus, 1927.

SERZEDELLO (Bento José Barbosa). - Arquivo Histórico da Veneravel Ordem Terceira de Nossa Senhora do Monte do Carmo Erecta no Rio de Janeiro desde sua fundação em 1648 até 1872. Rio de Janeiro. Tipografia Perseverança. 1872.

TORRES (Joäo Camilo de Oliveira) . - História de Minas Gerais. Belo Horizonte, Difusão Pan-Americana do Livro. 1961.

VASCONCELlos (Diogo de). - História do Bispado de Marianna. Belo Horizonte. Ediçōes Apolo. 1935.

VIANNA (Oliveira). - Populações Meridionaes do Brasil. São Paulo. Companhia Editora Nacional. 1933.

VIEGAS (Augusto). - Notícia de São João del-Rei. Belo Horizonte. Imprensa Oficial. 1953. 